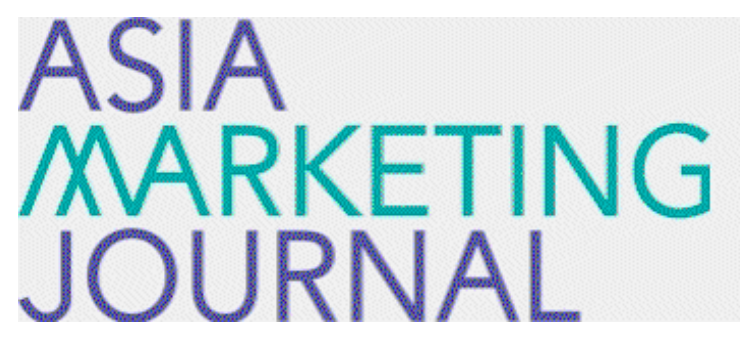

ASIA MARKETING JOURNAL

Volume 1 | Issue 2

Article 6

3-1-1999

\title{
기술 제품의 조직내 확산과 혁신저항
}

Dae Ryun Chang

Seong Do Cho

Follow this and additional works at: https://amj.kma.re.kr/journal

Part of the Marketing Commons

\section{Recommended Citation}

Chang, Dae Ryun and Cho, Seong Do (1999) "기술 제품의 조직내 확산과 혁신저항," Asia Marketing Journal: Vol. 1 : Iss. 2 , Article 6.

Available at: https://doi.org/10.53728/2765-6500.1012

This Article is brought to you for free and open access by Asia Marketing Journal. It has been accepted for inclusion in Asia Marketing Journal by an authorized editor of Asia Marketing Journal. 


\section{기술 제품의 조직내 확산과 혁신저항}

장 대 련

(연세대학교 경영학과 교수)

조 성 도

( 연세대학교 경영학과 박사과정)

\section{Intraorganizational diffusion and innovation resistance of high technology products}

Dae-Ryun Chang

Seong-Do Cho

본 연구는 기업이 기술제품을 도입한 후에 내부에 확산시키려고 하는 실행단계에서 직면하는 혁신저항에 영향을 미치는 요인과 혁신저항을 줄이고 확산을 증진시키는 확 산촉진활동을 설명하여 $2 \mathrm{~B}$ 마케팅 상황에서 기술제품의 조직내 혁신저항-확산모델을 도출하였다. 기업에서 기술제품을 조직내에 확산시킬 때는 구성원들의 혁신저항을 접하 게 된다. 소비자 행동에서는 혁신저항에 영향을 주는 변수로 개인변수와 제품변수를 제 시하고 있지만 $2 \mathrm{~B}$ 마케팅에서는 조직구조변수와 구매센터변수가 추가적으로 영향을 주 게 된다. 중앙집권화, 공식화정도가 높은 기업에서는 구성원들이 혁신저항을 가지면서 도 사용할 수 있다. 이러한 경우에는 판매기업과 구매기업의 관계가 단기적인 관계로만 그칠 수 있다. 또한 구매센터 참여정도가 적고 구매센터가 집중화되어 있으면 혁신저항 이 커지고 단기적인 관계만 형성될 가능성이 커진다. 그리고 제품의 지각된 위험, 적합 성에 따라 혁신저항의 정도가 달라질 것이다. 그리고 사용자 개인의 지각된 자기능력, 현 제품의 만족도 등이 의미있는 조절 변수 역할을 할 것이다. 그러므로 장기적인 관계 로 이어지기 위해서는 혁신저항을 줄이는 교육훈련, 제품개선, 부서간 조정, 개인적 동 기 부여와 같은 확산촉진활동이 있어야 한다. 따라서 본 연구를 통해 판매기업과 경영 자들은 기술제품에 대한 혁신저항을 극복하고 제품을 확산시킬 수 있는 학문적, 관리적 시사점을 얻을 수 있을 것이다. 


\section{1. 서 론}

기업이 소프트웨어, 워크스테이션, 패킷 통신서비스와 같은 첨단 기술제품을 구매할 때 구매센터(buying center)에서 결정한다. 그러나 도입된 이후에 기업내 구성원들이 얼마나 적극적으로 사용하느냐는 또 다른 문제이다. 기술 제품이나 정보시스템이 기업 내부에 도 입된 후, 기술 자체는 뛰어나지만 사용되지 않고 방치되는 경우가 많다. 예를 들어 A연구소 에서는 워크스테이션을 도입하여 방대한 양의 고객 패널 데이터를 관리, 활용하려고 했는 데 구성원들이 유닉스(unix) 언어와 데이터 처리 방법을 모르고, 데이터 관리부서와 사용부 서간에 업무협조가 원활하지 않아 워크스테이션 활용은 거의 없었던 사례가 있다. 이와 같 은 기술 제품의 조직내 확산은 구매기업뿐만 아니라 판매기업에도 중요한 문제이다. 왜냐 하면 구매기업 구성원들이 적극적으로 사용해야만 구매기업과 장기적인 관계를 형성하여 기업의 성과를 높일 수 있기 때문이다. 따라서 기술제품의 조직내 확산 (intraorgani zati onal diffusi on) 과 혁신저항을 극복하는 것은 기업간 마케팅 $1_{\text {(busi ness to }}$ busi ness marketing; 장대련, 1997) 에서 중요한 관리적, 학문적 의미를 가지고 있다.

마케팅에서 수용, 확산연구는 계량적인 연구(Bass, 1980; Mahaj an and Mul Ier, 1979) 와 소 비자 행동이론에서 많은 관심을 가져왔다. 그러나 중요한 관리적 의미를 가지면서도 관심 을 갖지 못한 영역이 $2 \mathrm{~B}$ 마케팅 상황에서 첨단 및 혁신 제품의 수용과 확산에 관한 분야이 다. 물론, 조직이론을 중심으로 조직 혁신성(innovativeness)에 대한 연구가 행해져 왔다 (Rogers, 1983; Zal tman, Duncan and Hol bek, 1973; Damanpour, 1991). 그러나 이러한 연구 는 마케팅 관점에서 볼 때 시사하는 바가 제한적이다. 또한 마케팅 분야에서 기업단위의 혁신 수용과 확산 연구도 소수에 불과하다(Gati gnon and Robertson, 1989; Robertson and Gati gnon, 1986). 그리고 혁신저항 극복에 관한 연구는 개별적인 소비자 수준에서만 행해졌 고 조직차원의 혁신저항은 거의 연구되지 않았다.

따라서 본 연구에서는 $2 \mathrm{~B}$ 마케팅 상황에서 혁신저항과 확산에 대한 중요한 학문적, 관리 적 이슈를 다음과 같이 제시하고자 한다.

첫째, 수용, 확산에서 관심을 가져야 할 분야는 혁신 저항(i nnovati on resi stance) 이다. 지 금까지는 소비자나 기업이 긍정적으로 반응하는 것에만 초점을 맞춰왔지만 제품을 사용하 는 소비자나 기업의 구성원은 새로운 기술제품이 도입되었을 때 저항하게 된다. 따라서 이 를 극복할 때에만 수용, 확산될 수 있다(Sheth, 1981; Ram 1987). 또한 기업이 기술제품을 구매하여 조직내에 확산시킬 때 생각해 볼 수 있는 것은 조직 구성원이 태도면에서는 저항 하면서도 조직구조 등 외부적인 압력 때문에 사용할 수 있다는 측면이다. 이러한 상황에서

1) 이하 $2 \mathrm{~B}$ 마케팅 
한 국 마 케 팅 저 널 제 1 권 제 2 호 는 장기적으로 제품을 반복구매하고 사용할 것이라는 기대를 할 수 없다 $(\mathrm{Km}$ and Srivastava, 1998). 따라서 혁신저항을 극복할 수 있는 다양한 마케팅전략과 경영전략이 필 요하다( Ram 1989) .

둘째 기업이 소프트웨어, 워크스테이션과 같은 기술제품을 구매하는 상황에서, 초기에 제 품을 시험구매하여 수용할 때 영향을 미치는 요인뿐 아니라, 조직 내부의 구성원들이 실제 로 사용하는 확산단계 ${ }^{2}$ 에 영향을 주는 요인을 밝히는 것이 중요하다. 지금까지의 연구는 초기의 수용단계에 초점을 맞춰왔었다( K m and Srivastava, 1998).

셋째, 조직이론에서 수용, 확산연구는 초기단계와 실행단계를 이중모델( anbi dextrous model)로 구분하여, 각 단계마다 다른 조직관련 변수가 영향을 미칠 것이라고 제안하였다 (Duncan, 1976: 1979; Damanpour, 1991). 그러나 조직단위의 변수 즉, 조직구조변수나 의사 결정자 관련 변수만을 고려하였을 뿐 사용하는데 영향을 미치는 개인변수에는 초점을 맞추 지 못했다. 따라서 이러한 개인변수를 파악하는 것이 필요하다(Gati gnon and Robertson, 1989; Damanpour, 1991).

그러므로 본 연구에서는 $2 \mathrm{~B}$ 마케팅 상황에서 기업이 기술제품을 구매했을 때 내부의 구성원들이 사용하거나 저항하는데 영향을 주는 요인과 혁신저항 극복에 관한 이론적 배 경과 모델, 명제 및 관리적 시사점을 제시해 보고자 한다.

\section{2. 이론적 배경}

\section{2-1. 수용, 확산에서 혁신저항}

셰스(Sheth, 1981) 는 마케팅의 수용, 확산 연구에서 간과되고 있는 중요한 요소가 혁신저 항(innovation resi stance) 이라고 제시하였다. 이러한 혁신저항에 관한 모델은 램(Ram 1987) 이 처음으로 정립하였는데 모델은 (그림 1) 과 같다.

저항은 현재 상태에서 변화하기를 거부하는 소비자의 상태이며 변화에 의해서 느끼는 위 협감과 관련된다(Ram 1987). 잘트만과 월렌도르프(Zal tman and Wal I endorf, 1983) 는 저항 을 '이전 상태를 변경하도록 하는 압력에서 이전 상태를 유지하려고 하는 어떤 행동'으로 보고 혁신저항을 '혁신을 수용하지 않으려는 태도'로 정의하였다. 소비자 행동이론에서는 혁신확산에서 혁신저항이 극복될 때 수용과 확산이 일어난다고 제시하고 지각된 자기 능력 (self-efficacy), 현 제품에 대한 만족도, 습관 등이 혁신저항에 영향을 미침을 밝혔다 ( El I en, Bear den and Shar ma, 1991; Ram 1987: 1989).

2) 이 단계를 로저스(Rogers, 1983) 는 실행(i mpl enentati on) 단계라고 하였다. 
( 그림 1) 램(Ram) 의 혁신저항 모델

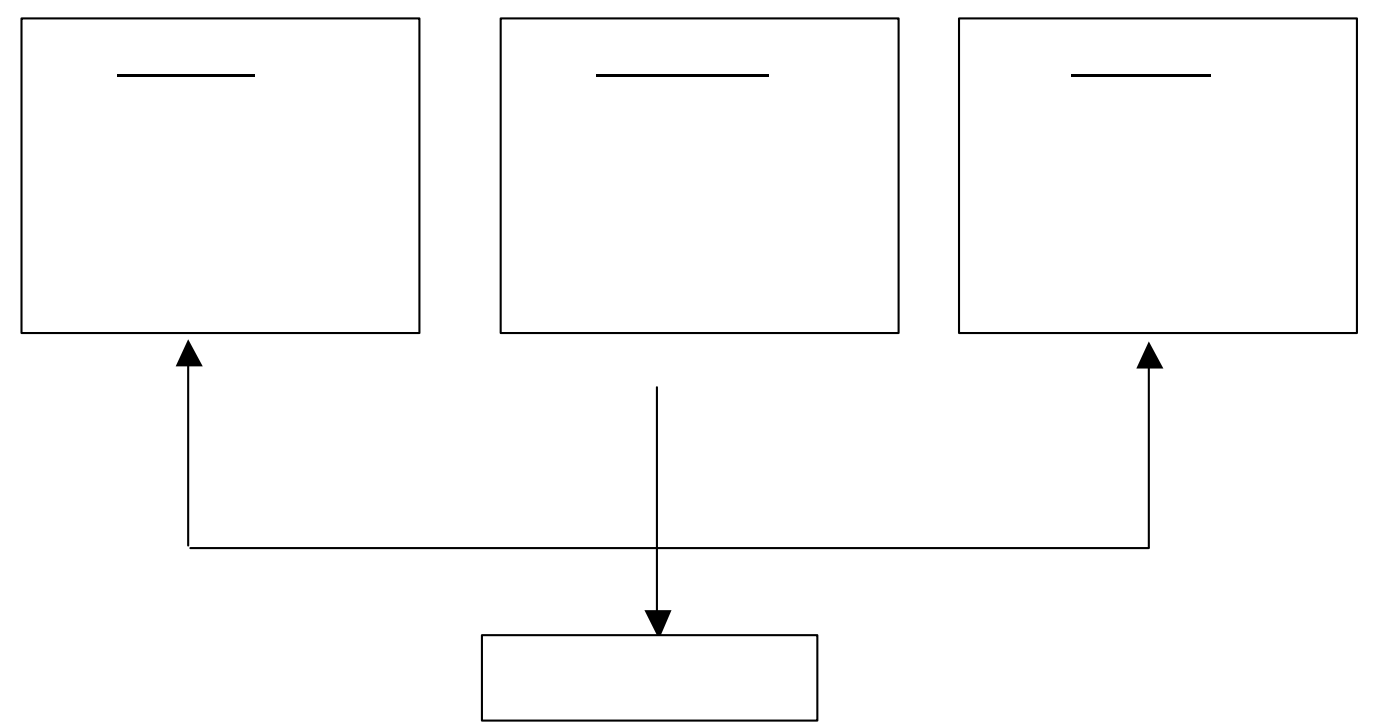

자료원 : Ram S. (1987), "A Mdel of I nnovati on Resi st ance," Advances in Consuner Research, p. 209. 요약정리한 것임.

그러나 조직체 구매의 실행단계에서는 개인관련 변수뿐만 아니라 조직단위 변수까지 영 향을 미치기 때문에 복합적인 연구가 필요하다. 그러나 조직구매의 혁신저항에 대한 연구 는 탐험적으로만 행해졌다(Gati gnon and Robertson, 1989) .

그리고 소비자행동 연구에서는 혁신저항을 극복할 수 있는 전략을 제시하였는데 구전, 대중매체를 통한 광고, 제품수정 등이 혁신저항의 원인에 따라 다르게 제시되었다( Ram 1989). 이와 마찬가지로 기술제품에 대한 혁신저항 연구에서도 저항을 극복할 수 있는 전 략이 필요하다. 기업내에서 혁신적인 구성원의 영향력 증대, 제품 개선, 비공식 조직의 활 용, 부서간 관계의 조정, 교육훈련을 통한 자기 지각 능력 향상 등이 예가 될 수 있을 것이 다( Wbodsi de, 1996).

\section{2-2. 개인수준의 확산이론}

확산이론은 사회학, 커뮤니케이션 이론, 마케팅, 조직이론, 교육학 등 학제간 성격 (interdi sciplinary nature) 을 가지고 있다. 이러한 이론을 가장 효과적으로 통합한 것이 커뮤니케이션 이론을 바탕으로 한 로저스(Rogers, 1983)의 확산이론이다. 로저스는 개인수 준에서 확산이론을 확립하였지만 조직차원에도 적용될 수 있다고 보았다. 로저스의 개인수 준의 수용과정은 지식, 설득, 결정, 실행 단계를 거치게 된다. 이는 개인이 혁신제품을 수 
한 국 마 케 팅 저 널 제 1 권 제 2 호 용할 때까지를 과정으로 보고 설명한 것이다. 이외에도 로저스는 개인의 혁신적 행동에 영 향을 주는 혁신제품 특성으로 상대적 이점(rel ative advantage), 적합성(compatibility), 지각된 위험(percei ved risk), 복잡성(compl exi ty), 관찰가능성(observabi lity) 등을 제시 하고 있다(Rogers, 1983).

그러나 혁신제품 특성으로 혁신적 행동을 설명하는 것 외에 개인의 성격, 인지방식 (cognitive style), 인지학습(cognitive learning), 지각된 자기능력(self-efficacy) 등으 로 설명하려는 시도들이 있다.

결국, 개인의 혁신 행동은 개인 특성인 성격, 인지방식, 인구통계적 특징과 상대적 이점, 적합성, 지각된 위험과 같은 혁신 제품 특성으로 설명할 수 있다. 상호작용적 관점은 이 두 관점을 모두 고려한 것이다.

이러한 개인수준의 수용, 확산이론은 경영정보 시스템분야에도 적용되어 기업내에 스프 레드 시트(spreadsheet) 소프트웨어와 같은 혁신제품을 도입하였을 때 최종 사용자가 어떻 게 수용하여 사용하는지에 대한 실행차원의 연구가 행해졌다 $\mathrm{Br}$ ancheau and Wetherbe, 1990). 그러나 조직차원의 영향요인이 고려되지 않았기 때문에 미래 연구에서 개인수준과 조직수준 요인의 관계와 영향정도가 동시에 밝혀져야 할 필요성이 제시되었다 $\mathrm{Brancheau}$ and Wet her be, 1990) .

\section{2- 3. 조직내 수용, 확산}

조직수준의 수용, 확산 연구는 조직이론이 중심이다. 연구 흐름은 크게 두 가지로 나눌 수 있는데 조직의 혁신성과 수용, 확산과정이다.

먼저 조직단위 변수와 수용, 확산의 관계가 주관심사였다. 조직의 전문성, 기능적 차별화, 공식화, 중앙집권화, 경영자의 재임기간, 리더쉽, 경영자의 혁신 추진 강도, 외부 의사소통, 내부 의사소통, 수직적 계층화, 부서간 갈등, 업무 의존도 등이 주요 변수들이 다. (Damanpour, 1991; K m and Sri vastava, 1998) 이러한 변수들과 수용과 확산 관계에 조 절변수로서 영향을 주는 것은 혁신 형태와 혁신 단계가 있다. 혁신 형태는 기술적인 혁신 - 관리적 혁신(admini strative i nnovati on), 제품혁신- 과정혁신, 급진적 혁신- 점증적 혁신으 로 구분하고, 혁신 단계는 초기의 수용단계인가 아니면 실행단계인가를 가리킨다. 이러한 혁신 형태와 단계는 앞에서 언급한 조직변수와 수용, 확산 관계에서 조절 효과(noderating effect) 를 갖는다.

예를 들어 조직의 전문성은 초기 수용단계에서는 의미 없는 변수이지만 실행단계에서는 긍정적 영향을 미치는 변수이다. 그리고 기능적 차별화는 초기단계에는 부정적 영향을 주 는 변수로 실행단계에서는 긍정적 영향을 주는 변수로 나타났다(Damanpour, 1991). 
한 국 마 케 팅 저 널 제 1 권 제 2 호

위와 같은 조직의 특성과 혁신 수용, 확산과의 관계를 종합하면 (표 1)과 같다. (표 1) 은 조직이론의 혁신성, 확산이론, 마케팅 연구를 종합하여 독립변수, 조절변수, 종속변수로 요약한 것이다.

(표 1) 조직 단위 혁신 연구에서 주요 변수

\begin{tabular}{|l|l|l|}
\hline 독립변수 & \multicolumn{1}{|c|}{ 조절변수 } & 종속변수 \\
\hline 공식화 & 혁신의 형태 & \\
중앙집권화 & - 기술적 혁신 vs 관리적 혁신 & 조직 혁신성 \\
업무의존도 & - 제품혁신 vs 과정혁신 & 혁신 확산 \\
조직 전문성 & - 급진적 혁신 vs 점증적 혁신 & 혁신 저항 \\
기능적 차별화 & & \\
조직의 크기 & 혁신의 단계 & \\
리더쉽 & - 초기단계 \\
최고경영자의 추진 강도 & 실행단계 & \\
내, 외부 의사소통 & & \\
경영자 재임기간 \\
수직적 계층화
\end{tabular}

자료원 : 로저스(Rogers, 1983), 가티옹과 로버트슨(Gati gnon and Robertson, 1989) 다만포르( Damanpour, 1991) 를 종합 정리한 것임

둘째로 조직단위 확산을 과정으로 보는 관점이다. 로저스는 확산과정을 초기단계 ( i nitiation) 와 실행단계로 나누고 이 모델을 (그림 2) 와 같이 요약하였다.

이러한 조직단위 수용, 확산연구에서 지적되고 있는 것은 개인차원이나 환경차원의 변수 가 고려되지 않았다는 것이다. 단순히 조직구조 차원의 변수뿐만 아니라 혁신제품을 수용, 사용하는 의사결정자와 구성원과 관련된 변수와 환경변수를 모두 고려하는 것이 필요하다 (Gat i gnon and Robertson, 1989; Damanpour, 1991). 그리고 2B 마케팅 상황에서 조직특성과 혁신저항의 관계는 거의 연구되지 않았다. 따라서 이에대한 구체적인 관계정립과 연구가 필요하다.

(그림 2) 조직의 혁신과정 모델
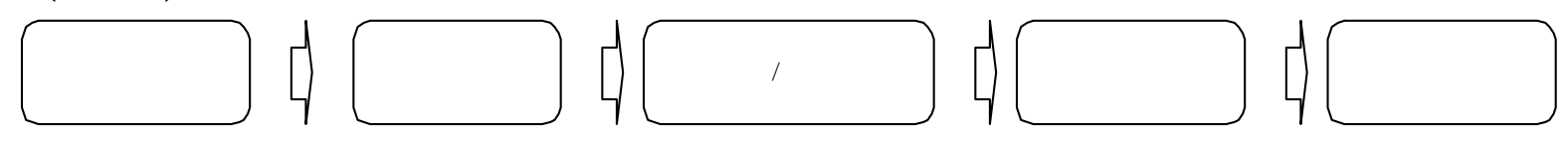

초 기 단 계

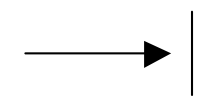

실행단계

1999.3 
2- 4. 2B 마케팅에서 구매센터

$2 \mathrm{~B}$ 마케팅에서 대표적인 개념중의 하나가 구매센터이다. 그리고 구매센터는 직책이 아니 라 역할을 의미한다( 장대련, 1997).

이러한 구매센터에서 제품구매를 결정하게 되는데 구매후 조직내부 구성원들이 얼마나 신속하게 수용하여 사용하느냐는 구성원의 구매센터 참여정도, 구매센터의 크기, 구매센터 의 중앙 집권화정도에 따라 달라질 수 있다(K mand Srivastava, 1998). 그러나 구매센터가 확산에 영향을 주는 과정에서 혁신저항을 먼저 극복해야 하기 때문에 구매센터 변수들은 확산이전에 혁신저항에 영향을 줄 것이다.

\section{3. 기술제품의 조직내 확산과 혁신저항}

김과 스리바스타바 Ki m and Srivastava, 1998) 는 기업이 구매센터를 통해 기술제품을 수 용한 이후에 조직내부의 구성원들 사이에 확산하는 과정에 초점을 맞췄다. 김과 스리바스 타바(K mand Srivastava, 1998)가 제시한 실행단계의 확산모델을 요약하면 (그림 3) 과 같 다. 본 연구에서는 김과 스리바스타바 연구에서 제시되지 못한 혁신저항과 개인 변수에 초 점을 맞춰서 혁신저항이론, 수용 확산이론, $2 \mathrm{~B}$ 마케팅, 조직이론과 혁신저항을 극복하기 위 한 확산 촉진활동을 체계화하여 (그림 4) 와 같이 기술제품의 조직내 혁신저항- 확산 모델을 제시하였다. 이 모델의 특징을 설명하면 다음과 같다. 첫째, 기업에서 시험구매 형태로 구 입한 제품이 가져올 수 있는 구성원들 사이의 혁신저항을 도입하였다. 둘째, 로저스의 조 직내 확산 과정에서 실행단계에 범위를 두었다. 셋째, 조직 특성, 구매센터, 제품변수외에 개인변수를 도입하였다. 구매센터를 중심으로 조직단위의 구매를 결정할 때는 각 사용자와 관련된 개인변수가 고려되지 않을 수도 있지만 조직내부에 사용자들 사이에 확산될 때는 각 구성원의 개인특성이 작용하기 때문이다. 넷째, 혁신저항을 극복하고 조직내 확산을 촉 진하는 효과를 제시하여 혁신저항과 확산의 동태적인 관계를 설명하였다. 다섯째, $2 \mathrm{~B}$ 마케 팅 상황을 고려하여 저항하는 태도를 가지면서도 조직특성 변수로 인해 단기적으로 사용할 수 있는 확산형태를 제시하였다.

\section{3-1. 종속변수 : 혁신저항과 조직내 확산}

신제품 개발을 배경으로한 소비자 행동이론에서는 혁신저항을 소비자의 태도변수로 보 고 혁신저항이 극복될 때만 소비자의 수용이 일어난다고 보았다(Ram 1987: 1989; ElI en, Bearden and Sharma, 1991). 그러나 개인변수외에도 기타 요소가 작용하는 2B 마케팅에서는 
한 국 마 케 팅 저 널 제 1 권 제 2 호 상황이 다르다. 개인수준에서 혁신저항을 가지더라도 중앙집권화, 공식화와 같은 조직특성 이 실행단계에서 제품을 사용하겠금 강제력을 가질 수 있기 때문이다. 따라서 $2 \mathrm{~B}$ 마케팅에 서 조직내 확산은 단순히 사용하고 있는지에 대한 것뿐만 아니라 사용자가 저항감을 가지 면서도 사용할 수 있다는 것을 고려해야 한다. 따라서 본 연구모델은 혁신 저항이 극복된 다음에 수용이 일어난다는 소비자행동 이론과 달리 태도 변수인 혁신저항과 확산을 동시에 분석하였다. 확산은 단순한 사용여부가 아니라 사용정도로 보았다.

그러나 혁신저항은 확산과의 관계에서 동전과 같은 양면 관계가 아니다(Ram 1989). 조직 체 구매에서 혁신저항에 대한 연구는 가티옹과 로버트슨(Gati gnon and Robertson, 1989)이 탐험적으로 하였는데 혁신저항을 단순히 수용하지 않은 것으로 정의하고 탐험적으로 실증 하였다.

( 그림 3) 김과 스리바스타바의 조직내 기술제품 확산 모델

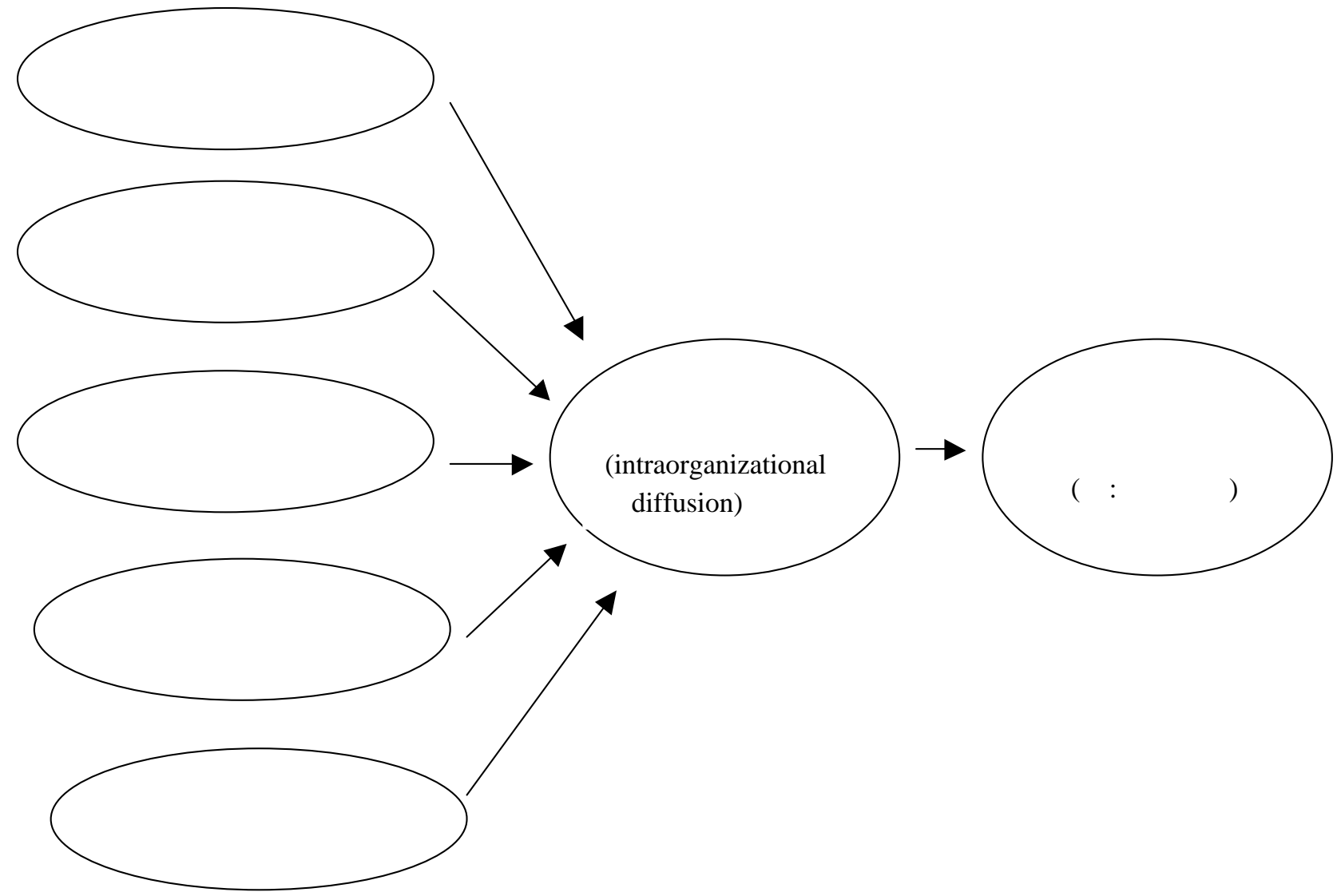

자료원: Kim Nam Woon and Rajendra K. Srivastava (1998), "Managing Intraorganizational Diffusion of Technological Innovations," Industrial Marketing Management, 27, p.233. 
( 그림 4) 기술제품의 조직내 혁신저항 확산 모델

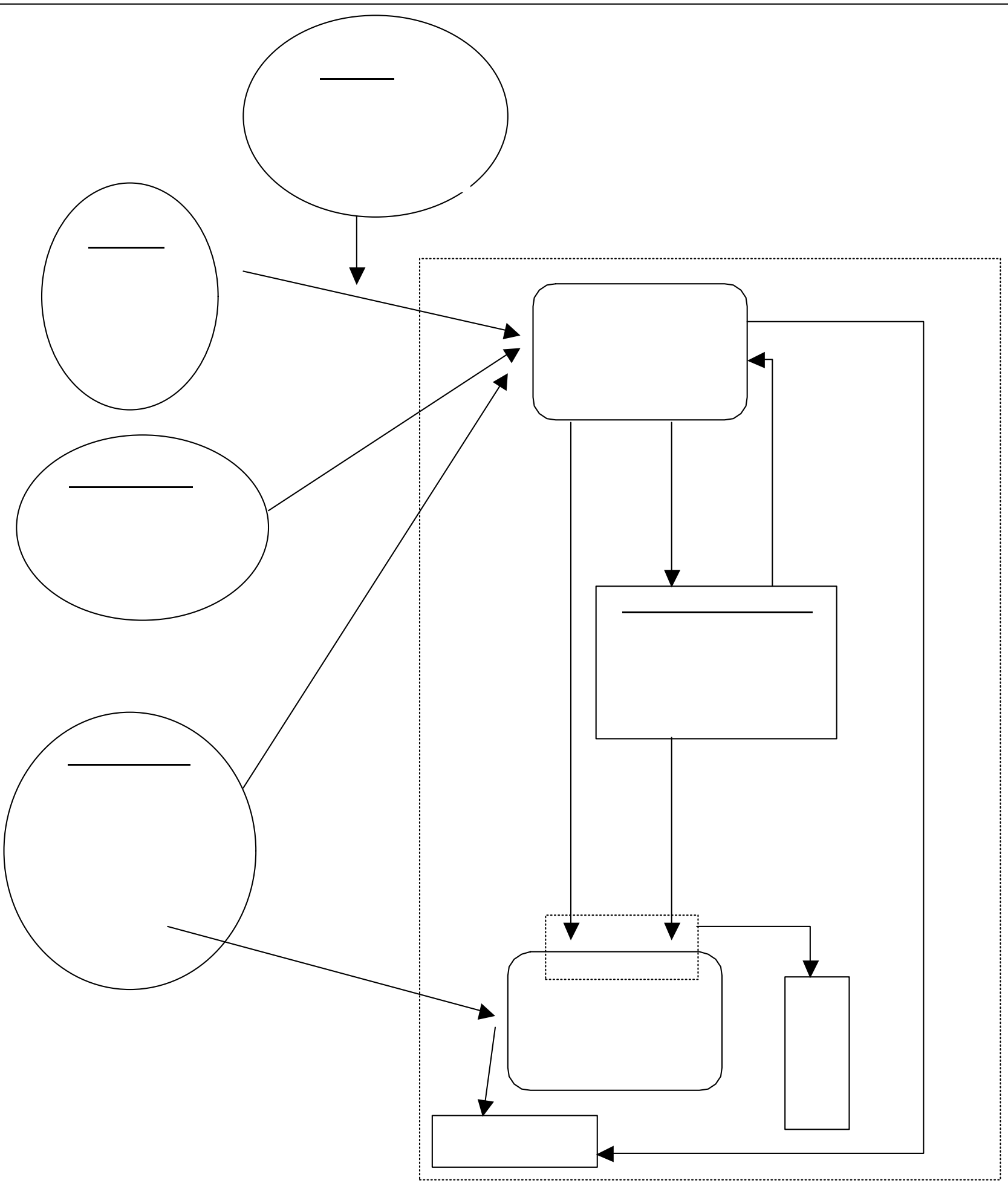


한 국 마 케 팅 저 널 제 1 권 제 2 호 이 연구는 기존 혁신저항 개념과 달리 혁신저항을 수용과 독립적인 개념으로 보지 않고 수용의 반대 개념으로 보았다. 하지만 결과는 단순히 수용과 혁신저항이 양면적인 관계가 아니고 혁신저항 자체에 영향을 미치는 변수가 독립적으로 있음이 밝혀졌다. 본 연구의 모 델은 가티옹과 로버트슨의 연구와 달리 실행단계이고 혁신저항을 기존 혁신저항 이론에 따 라 태도변수로 정의하였다(Zal tman and W由llendorf, 1983). 또한 혁신저항과 확산과의 관계 는 단순한 인과관계가 아니고 램(Ram 1987)의 모델처럼 두 변수사이에 여러 요인들이 작 용할 수 있다. 특히 초기 수용단계가 아니라 실행단계에서는 더 크게 작용할 것이다.

소비자 행동이론에서는 혁신저항이 제품수정, 구전, 광고 등에 의해 극복될 때 개별 소비자 가 혁신제품을 수용한다고 보았다(Ram 1987). 하지만 2B 마케팅 상황에서는 개인적인 수용 뿐만 아니라 조직 특성이 작용하기 때문에 혁신저항과 확산사이에는 다른 역학관계가 존재 할 수 있다. 위에서도 언급한 것처럼 저항하는 태도가 있으면서도 조직차원의 강제력 때문 에 사용할 수 있다. 이러한 경우에는 구매기업이 반복적인 구매를 하지 않고 판매자- 구매 자 관계가 단기적인 관계로 끝날 수 있다(Kimand Srivatava, 1998; Woodsi de, 1996). 또한 혁신저항과 확산과의 관계에서 다양한 확산 촉진활동을 통해 혁신저항이 극복되어 확산이 증가할 수 있다. 하지만 혁신저항이 극복되지 못할 때는 구매센터의 결정으로 초기 구매는 되었지만 구성원들의 혁신저항으로 인해 단기적인 구매로 그치고 장기적인 반복구매가 형 성되지 않을 수 있다(Jarvis and WI cox, 1977; TurnbulI and WIson, 1989).

\section{3-2. 조직 특성}

조직특성변수로는 부서간 갈등, 업무 의존도, 조직의 전문성, 의사소통정도를 포함하였 다. 이 변수들은 기존의 조직이론의 혁신연구에서 실행단계의 기술혁신 수용에 유의한 영 향을 미치는 것으로 나타났다(Damanpuour, 1991; K m and Srivastava, 1998). 중앙집권화와 공식화는 연구배경에 따라 다른 결과가 나왔다(Damanpour, 1991). 그러나 초기 혁신 수용단 계에서는 조직이 중앙집권화되어 있고 공식화되어 있으면 정보접촉의 제한 때문에 혁신수 용이 원활하지 않지만 실행단계에서는 높은 공식화와 중앙집권화가 구성원들을 독려하여 조직내 확산을 촉진시킬 수 있다( Ki mand Srivastava, 1998). 본 연구는 조직특성이 태도 변 수인 혁신저항에 먼저 영향을 미치고 혁신저항은 확산과 동태적인 관계를 가질 것으로 보 았다. 하지만 중앙집권화와 공식화는 혁신저항과 동시에 확산에도 직접적인 영향을 미치게 된다( K m and Sri vast ava, 1998).

명제 1 조직의 중앙집권화 정도가 클수록 기술제품의 조직내 확산은 커질 것이다. 
한 국 마 케 팅 저 널 제 1 권 제 2 호

명제 2 조직의 공식화 정도가 클수록 기술제품의 조직내 확산은 커질 것이다.

명제 3 부서간 갈등이 클수록 기술제품의 조직내 혁신저항은 커질 것이다.

명제 4 부서간 업무 의존도가 클수록 기술 제품의 조직내 혁신저항은 적어질 것이다.

명제 5 조직의 중앙집권화 정도가 클수록 기술제품의 조직내 혁신저항은 커질 것이다.

명제 6 조직의 공식화 정도가 클수록 기술제품의 조직내 혁신저항은 커질 것이다.

\section{3- 3. 구매센터}

구매센터는 $2 \mathrm{~B}$ 마케팅 연구에 있어서 핵심적인 개념이다. 구매센터는 환경의 불확실성, 업무의 불확실성, 제품 종류에 따라서 역동적으로 변화한다(Spekman and Stern, 1979; Spekman and Gronhaug, 1986). 조직특성에서 중앙집권화는 조직내 확산을 촉진시킬 수 있지 만 구매센터에서의 집중화는 다른 구성원의 참여를 제한하기 때문에 혁신저항을 일으킬 수 있다. 구매센터의 크기는 참여하는 구성원의 숫자를 말하고, 참여도는 구성원 구매결정의 의사소통과정에 얼마나 적극적으로 참여하느냐를 가리킨다. 구매센터 크기는 구체적인 숫 자를 말하며 집중화와 참여도는 조직의 분위기를 나타낸다. 따라서 구매센터의 크기가 크 고 참여도가 높을수록 초기 구매에 많은 구성원이 참여하기 때문에 구성원의 혁신저항을 감소시켜 줄것이다.

명제 7 구매센터의 집중화가 클수록 기술제품의 조직내 혁신저항은 커질 것이다.

명제 8 구매센터 크기가 클수록 기술제품의 조직내 혁신저항은 적어질 것이다.

명제 9 구매센터의 참여도가 클수록 기술제품의 조직내 혁신저항은 적어질 것이다.

\section{3-4. 제품특성}

로저스(Rogers, 1983) 와 램(Ram 1987) 은 제품 수용과 혁신저항에 영향을 미치는 여러 가지 제품특성을 제시하고 있지만 조직내부의 기술제품 확산과 관련이 있는 요소는 제품의 
한 국 마 케 팅 저 널 제 1 권 제 2 호 적합성, 복잡성, 관찰가능성이라고 할 수 있다(K mand Srivastava, 1998). 그리고 지각된 위 험(percei ved risk)은 소비자 행동의 중요 영향변수로서 물리적 위험, 기능적 위험( 성과 불 확실성), 심리적 위험, 사회적 위험으로 구성되어 있다. 관찰 가능성은 혁신의 결과가 다른 사람에 가시적으로 나타나는 정도를 가리킨다. 이것은 조직 구성원들에게 새롭게 채택된 기술을 학습하는 기회를 증가시켜준다. 적합성은 조직 구성원의 필요(needs), 과거경험, 습 관과 기술 제품간의 일치성을 말한다. 복잡성은 제품이 복잡한 정도를 의미하며 기술 제품 의 조직내 혁신저항을 커지게 한다. 특히 초보 이용자에게 부정적인 영향을 미칠 것으로 예상할 수 있다. 따라서 적합성이 혁신저항을 줄여주고 복잡성이 크면 혁신저항이 커지고 관찰가능성이 크면 혁신저항이 적어지고 지각된 위험이 크면 혁신저항이 커질 것이다.

명제 10 기술제품의 관찰가능성이 클수록 기술제품의 조직내 혁신저항은 적어질 것이 다.

명제 11 기술제품의 복잡성이 클수록 기술제품의 조직내 혁신저항은 커질 것이다.

명제 12 기술제품의 적합성이 클수록 기술제품에 대한 조직내 혁신저항은 적어 질것 이다.

명제 13 기술제품의 지각된 위험이 클수록 기술제품에 대한 조직내 혁신저항은 커질 것 이다.

3-5. 조절변수 : 개인변수

지금까지 기술제품의 혁신저항과 확산 연구에서 중요한 영향변수로 밝혀진 것은 지각된 자기능력(self-efficacy) 과 기존 제품의 만족도, 성격, 습관 등이다(Ellen, Bearden and Sharma, 1991). 지각된 자기능력은 새로운 기술제품을 사용할 수 있는 기술이나 능력이 본 인에게 어느 정도 있는지에 대한 자신감과 지각정도를 말한다. 이러한 지각된 자기능력이 클수록 혁신저항은 적어진다. 그리고 기존 제품에 대한 만족도가 클수록 혁신저항은 커질 것이다. 또한 KAl (Krton Adopti on I ndex) 와 같은 인지방식(cogni ti ve styl e) 지수에 따라 순 응자와 혁신자가 구분되고 혁신자일수록 혁신저항은 적을 것이다.

이와 같은 개인변수는 실행단계에서 조직에 관계된 변수인 구매센터, 조직특성과 제품특 성변수를 조절하는 역할을 할 것이다. 왜냐하면 초기수용 단계가 아닌 실행단계의 조직내 확산에서는 조직차원의 결정 다음에 개인수준의 결정이기 때문이다. 따라서 조직차원의 변 
한 국 마 케 팅 저 널 제 1 권 제 2 호 수들에 영향을 받은 개인이 각자의 특성에 따라 혁신저항과 확산을 하게 될 것이다.

명제 14 구매센터, 조직특성, 제품특성과 혁신저항의 관계에서 자기 지각능력이 큰 구성원이 자기 지각능력이 적은 구성원보다 혁신저항이 적을 것이다.

명제 15 구매센터, 조직특성, 제품특성과 혁신저항의 관계에서 기존 제품에 대한 만족 도가 큰 구성원이 기존 제품에 대한 만족도가 적은 구성원보다 혁신저항이 클 것이다.

3- 6. 혁신저항과 확산 관계와 장단기 효과

$2 \mathrm{~B}$ 마케팅에서 구성원의 저항하는 태도인 혁신저항은 다양한 전략을 통해서 극복되어 확산으로 이어질 수 있다. 부서간 관계 조정을 통해서 의사소통을 증진시키면 보다 원활한 관계로 인해 혁신저항이 극복될 수 있다. 그리고 지각된 자기능력이 적은 구성원은 교육 훈련과 서비스를 통해서 혁신저항을 줄일 수 있을 것이다(Ellen, Bearden and Sharma, 1991). 그리고 혁신적인 구성원을 통해 개인적인 영향을 줄 수 있을 것이다. 조직이론에서도 비공 식조직을 통해서 혁신활동이 원활하게 일어나는 것이 제시되었다 Hermini a, 1993). 그리고 소비자 행동이론에서 제시된 전략으로 제품 수정과 개선을 통해서 혁신저항을 감소시킬 수 있다( Ram 1989). 이러한 확산 촉진활동 효과가 혁신저항을 극복할 때는 구성원의 사용정도 는 증가하게 될 것이다. 기존 개인수준의 전략과 다른 점은 복잡한 조직적 특성이 고려되 어야 한다는 것이다. 이러한 확산 촉진활동을 통해서 혁신저항을 넘어설 때는 확산이 증가 하고 장기적인 관계를 통해 판매기업이 지속적인 경쟁우위를 가질 수 있다 $\mathrm{K} \mathrm{m}$ and Srivastava, 1998). 그러나 혁신저항이 극복되지 않을 때는 시험구매로 끝나서 단기적인 거 래만 이루어질 것이다. 그리고 혁신저항을 극복하지 못한 중앙집권화와 공식화에 의한 확 산효과도 단기적인 관계에 멈출 것이다.

명제 16 기술제품의 조직내 확산에서 확산 촉진활동 효과가 혁신저항보다 크면 확 산정도는 커질 것이다.

명제 17 기술제품의 조직내 확산에서 사용자의 혁신저항을 극복하지 못한 초기구 매는 단기적 관계만 형성할 것이다. 
명제 18 기술제품의 조직내 확산에서 사용자의 혁신저항을 극복하지 못한 공식화에 의한 확산은 단기적 관계만 형성할 것이다.

명제 19 기술제품의 조직내 확산에서 사용자의 혁신저항을 극복한 확산은 장기적 인 관계로 이어질 것이다.

\section{4. 시사점과 결론}

$2 \mathrm{~B}$ 마케팅에서 기업이 기술제품을 구매할 때 초기의 수용뿐만 아니라 사용하는 구성원이 어떤 반응을 보이느냐는 매우 중요하다. 본 연구는 실행단계의 기술제품이 조직 내의 혁 신저항을 극복하고 확산되기 위해서 어떤 조직특성 변수가 중요한지를 밝히고, 구성원 개 인에게 영향을 주는 지각된 자기능력과 현재 만족도, 습관 등이 중요함을 제시하였다. 그리 고 기술제품의 조직내 확산에서 간과하기 쉬운 혁신저항 개념을 제시함으로써 사용하는 개 인이 혁신을 저항하면서도 조직 특성에 의해 사용할 수 있음을 제시하였다. 이를 통해 조 직내의 사용자가 사용하고 있는 이유에 대한 깊은 이해를 할 수 있다. 그리고 혁신저항과 확산과의 관계 설명을 통해 기술제품이 조직내에 확산될 때 일어나는 혁신저항을 효과적으 로 극복하고 판매자 구매자간의 장기적인 관계를 형성하는 전략을 구체화하였다. 미래 연 구에서는 본 연구에서 제시한 명제를 실제 기업을 대상으로 실증함으로써 기업의 구매행태 와 혁신저항 확산을 보다 깊이 이해하는 것이 필요할 것이다. $2 \mathrm{~B}$ 마케팅에서 사용자가 혁신 저항 없이 장기적으로 기술제품을 사용할 때 판매조직과 구매조직은 장기적인 관계를 형성 하게 되고 판매기업은 지속적인 경쟁우위를 확보할 수 있을 것이다.

\section{참 고 문 헌}

장대련(1997), 2B Narketing; 기업지향 마케팅의 이해와 실천, 일송.

Bass, Frank M. (1980), "The Relationship between diffusion Curves, Experience Curves, and Demand Elasticities for Consumer Durable Technological Innovations," Journal of Business, 53(July), 551-557.

Brancheau, James C. and James C. Wetherbe(1990), "The Adoption of Spreadsheet Software: Testing Innovation Diffusion Theory in the Context of End-User Computing," Information System Research, 1(2), 115-143.

Damanpour, Fariborz (1991), "Organizational Innovation: A Meta-Analysis of Effects of 
Determinants and Moderators," Academy of Management Journal 34(September), 555590.

Ellen, Pam Scholder, William O. Bearden and Subhash Sharma (1991), "Resistance to

Technological Innovations : An Examination of the Role of Self-Efficacy and

Performance Satisfaction," Journal of the Academy of Marketing Science, Vol. 19, No. 4, 297-307.

Gatignon, Hubert and Thomas Robertson (1989),"Technology Diffusion: An Empirical Test of Competitive Effects," Journal of Marketing, 53(1), 35-49.

Herminia Ibarra (1993), "Network Centrality, Power and Innovation Involvement: Determinants of Technical and Administrative Roles", Academy of Management Journal, Vol. 36, No. 3, $471-501$.

Jarvis, L. P., and J. B. Wilcox (1977), "True Vendor Loyalty or Simply Repeat Purchase Behvior?'," Industrial Marketing Management 6, 9-16.

Kim, Nam Woon and Rajendra K. Srivatava (1998), "Managing Intraorganizational Diffusion of Technological Innovations," Industrial Marketing Management, 27, 229-246.

Mahajan, Vijay and Eitan Muller (1979), "Innovation Diffusion and New Product Growth Models in Marketing," Journal of Marketing, 43 (Fall), 55-68.

Ram, S. (1987), "A Model of Innovation Resistance," Advances in Consumer Research 14:208-212. Eds. Melanie Wallendorf and Paul Anderson, Provo. UT: Association for Consumer Research.

(1989), "Successful Innovation Using Strategies to Reduce Consumer Resistance:

An Empirical Test," Journal of Product Innovation Management 6:20-34.

Robertson, Thomas S. and Hubert Gatignon (1986),"Competitive Effects on Technology

Diffusion," Journal of Marketing 50(3), 1-12.

Rogers, Everett M (1983), "Diffusion of Innovation," 3rd ed. The Free Press, New York.

Ruekert, Robert W. and Orville C. Walker, Jr. (1987), "Marketing's Interaction with Other Functional Units," Journal of Marketing, January, 1-9.

Sheth, Jagdish N. (1981), "Psychology of Innovation Resistance: The Less Developed Concept (LDC) in Diffusion research," in Research in Marketing ed. N. Sheth, 4, Jai Press Inc., 273-282.

Spekman, Robert E. and Kjell Gronhaug (1986), "Conceptual and Methodological Issues in Buying center Research," European Journal of Marketing, 20(7), 50-63. and Louis W. Stern (1979), "Environmental Uncertainty and Buying Group Structure: An Empirical Investigation," Journal of Marketing, 43(spring), 54-64.

Turbull, Peter W. and David T. Wilson (1989), "Developing and Protecting Profitable Customer 
Relationships," Industrial Marketing Management 18, 233-238.

Woodside Arch G. (1996), “Theory of Rejecting superior, new technologies,” Journal of Business and Industrial Marketing, Vol. 11 NO. 3/4, 25-43.

Zaltman, G. and M. Wallendorf(1983), Consumer Behavior: Basic findings and Management Implications, New York: John wiley \& Son.

Zaltman, Gerald, Robert Duncan, and Jonny Holbek (1973), Innovations and Organizations, New York: Wiley. 